\title{
CONSTRUCTING AN ANTI-CORRUPTION THEOLOGY
}

\author{
Yahya Wijaya \\ Faculty of Theology Duta Wacana Christian University \\ Yogyakarta, Indonesia
}

In a class discussion of the ICRS Yogya ${ }^{1}$ course "Religion and Economics," in which the student composition comprises a Philippine and Indonesians, it was admitted that Indonesia and the Philippines are very religious countries in the sense that most of the people associate themselves to a particular religious institution and participate regularly in religious activities. Ironically, both countries are amongst the most corrupt in the world according to the experiences of those students, which are supported by the indices of Transparency International. The discussion led to a hypothesis that religions may not have an impact on people's attitude to corruption. The fact that the majority religion of Indonesia is Islam whilst that of the Philippines is Christianity may indicate that religious differences have no effect in regard to corruption.

\section{Isn't It Obvious that Corruption Violates Religious Teachings?}

Anti-corruption campaign has become an agenda of the interreligious movement in Indonesia. An interfaith organisation in collaboration with an NGO and an Islamic university in Yogyakarta publish a handbook intended as a practical guide for religious leaders in proclaiming the anticorruption attitude. The handbook, titled Korupsi dalam Perspektif Agama-agama [Corruption from the Perspectives of Religions], demonstrates that all major religions provide abundant resources for building an anticorruption morality among their adherents. ${ }^{3}$ Such resources include scriptural texts as well as contemporary doctrinal teachings. A similar exploration of multi-religious resources carried out by M. Subhi-lbrahim and Aan Rukmana ${ }^{4}$ arrives at the same view.

\footnotetext{
${ }^{1}$ ICRS Yogya (Indonesian Consortium for Religious Studies in Yogyakarta) is a consortium of three universities in Yogyakarta: Duta Wacana Christian University, Sunan Kalidjaga State Islamic University, and Gadjah Mada University. It offers an international PhD program in interreligious studies.

${ }^{3}$ Korupsi dalam Perspektif Agama-agama. Yogyakarta: LP3 Universitas Muhammadiyah Yogyakarta, Government Reform in Indonesia, Koalisi Antarumat Beragama untuk Antikorupsi, 2004 ${ }^{4} \mathrm{M}$. Subhi-Ibrahim and Aan Rukmana, "Agama untuk Antikorupsi" in Wijayanto and Ridwan Zachrie [eds], Korupsi Mengorupsi Indonesia: Sebab, Akibat dan Prospek Pemberantasan. Jakarta: Gramedia Pustaka Utama, 2009
} 
However, a recent study on the relationship between religion and corruption, carried out by Heather Marquette, indicates that the effectiveness of religious teachings is indeed doubtful. Marquette challenges the argument, such as that of S.D. Beets, that religious moral teachings regarding honesty, legality and treatment of others provide adherents of religions a strong reason for refraining from corruption. Pointing to the Transparency International's Corruption Perception Index [TI-CPI]) and the index of religiosity by the Pew Global Attitudes Project, Marquette shows that "many of the most corrupt countries in the world ... also rank high in terms of religiosity." 5

In many countries, corruption even infiltrates religious institutions including churches. Christoph Stueckelberger ${ }^{6}$ implies a worry about the notion so commonly held among Christians in certain countries which considers corruption in churches as normal as it is in the greater public life. In Indonesia, a recent report by the state's Commission for the Elimination of Corruption (KPK) shows that among the Indonesian government institutions the most corrupt is, ironically, the Ministry of Religious Affairs. ${ }^{7}$

Why are religions so powerless in facing corruption? Are those religious people involved in corruption not serious enough in practising their religions? Subhi-Ibrahim and Rukmana identify the failure of religious people in perceiving religious symbols as a reason why participation in religious activities does not result in anti-corruption behaviour. They explain that religious symbols, particularly in the form of rites, point to the essence of religion which contains social ethical commitments. However, many adherents of religions are trapped in symbolism-formalism in the sense that they tend to treat symbols as the essence, and therefore fail to recognise the true essence. In so doing, they alienate the seriousness in practising religious rites from social ethical commitment. ${ }^{8}$

Subhi-Ibrahim and Rukmana's argument is indeed worth supporting, but favourite religions in Indonesia, which are Islam and Christianity, emphasise not only rituals but also doctrines. Regular worships in mosques and churches as well as religious broadcasts via mass media show attempts to balance the ritual dimension and the doctrinal one. Are not

\footnotetext{
${ }^{5}$ Heather Marquette, Corruption, Religion and Moral Development. Religions and Development Working Paper 42, Birmingham: International Development Department University of Birmingham, 2010

${ }^{6}$ Christoph Stueckelberger, Corruption Free Churches Are Possible: Experiences, Values and Solutions. Geneva: Globethics.net, 2010

${ }^{7}$ Harian Kompas, 29 November 2011, p.3

8 Ibrahim, pp. 827-829
} 
religious doctrines more direct than rituals in delivering social ethical messages? As with religious symbols, religious doctrines are to serve what Subhi-Ibrahim and Rukmana call 'the essence of religion' with its social ethical dimension. However, the structure of religious doctrines tend to be God centred, in the sense that it is built around concepts of God, God's works and God's will whilst the social ethical messages tend to be less explicit. Therefore, whilst it is true that religious doctrines imply moral standards that should include condemnation of corruption, the actual practice of those doctrines do not always work that way. In other words, religious people participating in the practices of corruption are not always aware that they are confronting against the teachings of their religion. Marquette sees the problem lies in the area of interpretation. Religious people interpret differently which behaviours are categorised as corruption. According to Marquette, the way individual religious people interpret corruption is much influenced by the interpretation of their community and its degree of commitment to public morality. ${ }^{9}$ It is therefore important to identify characteristics of particular religious communities that can be related to people most likely involved in corruption.

\section{Corruption in the History of Indonesia}

Indonesian historian, Sri Margana, ${ }^{10}$ notes that corruption has existed since the age of the Javanese Kingdom of Mataram in pre-colonial times and continued to affect the economy during the Dutch administration. It is rooted in the patrimonial culture of the traditional kingdom which knew no separation between the property of the state and that of the ruler. According to Margana, the intensive interactions between the Javanese kings and the colonial particularly the officials of the Dutch political-trading power, the Vereenigde OostIndische Compagnie (VOC), had enhanced the patrimonial culture. For their business activities until the $18^{\text {th }}$ century included political projects to protect the patrimonial structure. Margana believes that corruption also became a common practice in the VOC management itself and in turn drove that company to its collapse in the early $20^{\text {th }}$ century. Taking over the bureaucratic positions from the Dutch after the Independence, Indonesian

\footnotetext{
${ }_{9}^{9}$ Marquette, Corruption, Religion and Moral Development

${ }^{10}$ Sri Margana, "Akar Historis Korupsi di Indonesia" in Wijayanto and Ridwan Zackrie [eds] Korupsi Mengorupsi Indonesia: Sebab, Akibat dan Prospek Pemberantasan. Jakarta: Gramedia Pustaka Utama, 2009, 417-442
} 
state officials inherited the culture of corruption and failed to prevent it from growing more and more massive in the following periods, from that of the Sukarno regime to the present.

Despite the existence of anti-corruption institutions sponsored by the state, strong resistance to corruption is not always a national consensus. Wjayanto ${ }^{13}$ explains that in 1970-1980s several influential Indonesian economists took the position of "corruption apologists", arguing that corruption may be needed to "grease the wheel" in the situation where bureaucracy and regulations were inefficient and out of date. ${ }^{14}$ According to those corruption apologists, corruption makes the economy more efficient by bypassing high-cost bureaucratic complication. Such a theory has been rejected by many other economists. Ari Perdana, for instance, argues that corruption apologists have overlooked the real factors required for a healthy, efficient economy. Those factors include the elimination of distortions rooted in the inefficient state bureaucracy. Corruption does not eliminate that, it is just a compromise which allows the inefficiency remain exist and even grow. ${ }^{15} \mathrm{~A}$ similar argument has also been suggested by Christopher Lingle, a sceptic of the idea of the "Asian Century." Analysing the economic and political situation in today's Asia including Indonesia, Lingle suggests that corruption in fact increases inefficiency in the economy rather than being a solution of it. He also believes that corruption destructs the moral dimension of business since it betrays real commercial and contractual values. ${ }^{16}$

In today's Indonesia, a justification of corruption is hardly heard, but corruption has been so widespread that no area of public life can be convincingly declared immune from it. Kwik Kian Gie, a prominent Indonesian economist, argues that corruption is the root of all economic and social problems being faced by Indonesian society. Kwik depicts the broad spectrum effect of corruption in the economic life of Indonesian society. Corruption in the legal institutions causes law uncertainty which obstructs investment. The lack of investment in turn results in high unemployment which raises the degree of poverty. Corruption also occurs in the institutions in charge of public security and order. In that case business institutions have to pay extra costs for what they have already paid through the tax

\footnotetext{
${ }^{13}$ Wijayanto, "Memahami Korupsi" in Wijayanto and Ridwan Zackrie [eds] Korupsi Mengorupsi Indonesia, 4-5

${ }^{14}$ Ari Perdana in the same book explains that those economists actually followed a theory promoted by Nathanael Leff and Samuel Huntington (Ari Perdana, "Biaya Ekonomi dan Korupsi: Perspektif Teori dan Empiris" in Wijayanto and Ridwan Zackrie [eds] Korupsi Mengorupsi Indonesia, 122)

${ }^{15}$ Ari Perdana, 124

${ }^{16}$ Christopher Lingle, The Rise and Decline of the Asian Century: False Starts on the Path to the Global Millenium. Hong Kong: Asia 2000 Ltd, 2000, 147
} 
structure. For Kwik, those practices of multiple expenses explain why Indonesian products are less competitive than those of neighbouring countries. ${ }^{17}$

\section{Corruption, Politics and the Indonesian Business Community}

Given the widespread of corruption in Indonesia, a study on corruption in Indonesia can focus on any sector of society. However, the practice of corruption involving the business and professional sectors is worth singling out because of the massive economic cost and extensive effect it produces. According to the 2011 edition of the Transparency International's Bribery Payers Index which examines the practices of bribery by business actors in 28 countries, Indonesia ranked $4^{\text {th }}$ in the list of countries where the business actors like to bribe ${ }^{19}$. Since Indonesian businesspeople, as Indonesians in general, are relatively religious, a special attention to their religiosity would be a significant contribution to a study concerning corruption in the Indonesian business context.

In a relatively emerging economy of Indonesia, the relation of business to politics is quite straightforward. Political changes, which are often ground-breaking in nature, affect all sectors of society including the business one. The change from the socialist-oriented regime of Sukarno to the 'New Order'20 in particular widened the access of the private sector to the Indonesian economy. As a result, large-scale business corporations started to play crucial role in the state's programme of 'Development.' Beside transnational and foreign corporations flooding into the country, large scale local firms also came into being. Given the crucial role of the political factor, the emergence of those local business institutions can be explained in term of political relation. First, there were major business actors whose businesses depended much on government projects and policies, and therefore often play double roles as businesspeople and politicians at once. In the era of Suharto, this type of business actors was made up mostly of the family members, relatives as well as close friends of Suharto and other state leaders whose business background is weak or even absent. Their businesses would have certainly been difficult to survive in a

\footnotetext{
${ }^{17}$ Kwik, Kian Gie, Pikiran yang Terkorupsi. Jakarta: Penerbit Buku Kompas, 2006, p.10

${ }^{19}$ see: bpi.transparency.org

20 'New Order' refers to the regime of Suharto, an army General who took over the power in 1965 after a successful military attack against the Communist camp. Suharto was forced to step down in 1998 when the country was facing a severe economic crisis.
} 
situation where corruption, particularly in the forms of collusion and nepotism ${ }^{21}$, was absent. It is therefore no wonder that prominent business leaders of this type are characterised by the ambition not only to win the contracts of government projects but also to acquire political positions in the parliament, political parties and the government.

Secondly, there were major business actors who came from the traditional business community. Taking the opportunity available in the new political atmosphere, they transformed their businesses from small or medium enterprises into giant corporations. A significant portion of this group is of the ethnic Chinese minority with a long history of being politically crippled and culturally scandalised. Consequently, despite their business expertise and experience, they tend to feel politically inferior and thus always need of political backing which state officials ready to offer, forming patron-client collaboration known as clientelism which is a serious type of corruption.

It is therefore obvious that the political factor plays a crucial role in the practices of corruption involving major Indonesian businesspeople. In the case of the first group of business actors, political capital is fundamental for their business; whilst in the case of the second group, political expenses are dominant part of their business calculation. Of course, politics is not the only factor driving the business actors into corruption. As has been described, corruption in countries like Indonesia is multidimensional. The cultural factor, such as that related to feudalism and the syndrome of the new middle class, is no less crucial than the political one. Since its multidimensional nature, corruption cannot be examined adequately from a single moral approach. It should be dealt with by perspectives of business and corporate ethics, social and personal ethics, as well as cultural and religious ethics altogether.

\section{The Religions of the Indonesian Businesspeople: The Significance of Christianity}

The religions the Indonesian businesspeople affiliated with vary. Many of them, particularly those close to political leaders are Muslims, including all family members of Suharto and Aburizal Bakrie, the owner of Bakrie Group and the chairperson of Golkar, the most powerful political party in Suharto's era. The owner of the once largest holding company in Indonesia, Liem Sioe Liong, who was an old friend of Suharto, was a Buddhist. However,

\footnotetext{
${ }^{21} \mathrm{cf}$ : Stueckelberger, 23
} 
among the ethnic Chinese businesspeople, Christianity has become increasingly attractive. The rest of this article will particularly focus on the relationship between Christianity and those ethnic Chinese businesspeople.

The inclination of the ethnic Chinese businesspeople toward Christianity is not an exclusively Indonesian phenomenon. A recent study by Joy Kooi-Chin Tong ${ }^{25}$ indicates that Christianity has become the most favourable religious tradition among the overseas Chinese businesspeople in various Asian countries. According to Tong, the open economy of China introduced by Deng Xiaoping has attracted many overseas Chinese to do business in the mainland whilst colouring China's business environment with Christian values and messages. This led to what labelled as "Christianity fever," which is a remarkable growth of Christianity in China motored by people working in the business and professional sectors. Apart from those common trends among the overseas Chinese, the Indonesian ethnic Chinese have particular reasons why Christianity is preferable. First, many ethnic Chinese are educated in Christian schools which have offered modern education since the colonial times. In the New Order era, it was not easy for ethnic Chinese children to enter public schools given the discriminatory policy practised in those schools. Christian schools, therefore, were the first option for them. Secondly, as a part of the political conflict with the Communist regime of China, the Indonesian government under Suharto showed an explicit hostility against Chinese culture. This created an inconvenient feeling among the ethnic Chinese to continue practising their traditional religions. In choosing an alternative religion for the traditional one, many ethnic Chinese preferred Christianity than Islam, given the history of uneasy relationships between ethnic Chinese communities and certain Islamic groups. ${ }^{26}$

\section{How Different Christian Traditions Address Corruption-related Issues}

In my earlier study on economic ethics and fundamentalism, ${ }^{27} \mathrm{I}$ argue that the Christian communities that are most attractive to the urban business community can be identified as

\footnotetext{
${ }^{25}$ Joy Kooi-Chin Tong, Overseas Chinese Christian Entrepreneurs in Modern China: A Case Study of the Influence of Christian Ethics on Business Life. London, etc: Anthem Press, 2012.

${ }^{26}$ See: The Siauw Giap, "Islam and Chinese Assimilation in Indonesia and Malaysia” in Cheu Hock Tong [ed], Chinese Belief and Practices in Southeast Asia. Petaling Jaya: Pelanduk Publications, 1993, 63-66

${ }^{27}$ Yahya Wijaya, "The economic ethics of Christian and Islamic fundamentalism" in Hadsell, Heidi and Stueckelberger, Christoph, Overcoming Fundamentalism: Ethical Responses from Five Continents. Geneva: Globethics.net, 2009
} 
either neo-Pentecostal ${ }^{28}$ or conservative-evangelical. ${ }^{29}$ Neo-Pentecostal churches are often associated with the doctrine of prosperity gospel, whilst the conservative-evangelicals emphasise individual piety as a response to individual salvation.

\section{The Prosperity Gospel and the Spirit of Entrepreneurship}

The doctrine of prosperity gospel is central in the messages of neo-Pentecostal churches and observably practised in the lifestyle of their leaders. Many academic theologians would stand by Stueckelberger in condemning that doctrine as a "modern form of simony" which provides spiritual justification for corruption. ${ }^{31}$ However, Rony Kristanto ${ }^{32}$ interprets that doctrine more positively. Based on a field research in the largest neo-Pentecostal church in Solo, Central Java, he concludes that the prosperity gospel is an attempt of the neoPentecostals as a minority group to provide a theology which is compatible with the need to build optimistic mentality in order for them to survive in a politically vulnerable situation. A similar argument is suggested by Lovemore Togarasei ${ }^{33}$ who claims that the prosperity gospel has contributed to poverty alleviation in Africa by changing the people's mentality toward a more compatible one with the post-colonial situation as well as the global market condition. Togarasei points to the preaching of a particular neo-Pentecostal figure emphasising entrepreneurship and its implication to wealth creation. Opposing the accusation that the prosperity gospel is simply a version of materialism, he contends that the teaching in fact covers all dimensions of individual life. The role the prosperity gospel in fostering entrepreneurship can also be noticed among the Overseas Chinese business community in China as observed by Tong. ${ }^{34}$ In short, Kristanto and Togarasei as well as Tong

\footnotetext{
${ }^{28}$ For the characteristics of Neo-Pentecostal churches in comparison to the traditional Pentecostal churches, see: Rijnardus van Koij and Yam'ah Tsalatsa A. Bermain dengan Api: Relasi antara Gereja-gereja Mainstream dan Kalangan Kharismatik Pentakosta. Jakarta: BPK, 2007: 6-8. One of large Neo-Pentecostal congregations, The Mawar Saron Church, has been mentioned in John Mansfrod Prior "The Challenge of Pentecostals in Asia, Part One: Pentecostal Movements in Asia" Exchange, 36 (2007), 31

${ }^{29}$ The term 'conservative-evangelicalism' refers to the Protestant denominations affiliated with Western (mostly American) evangelical churches. Those churches claim to be the defender of fundamental Christian doctrines which, for them, include literal acceptance of the Bible, personal conversion and the so called 'the Great Commission.' See, Hwa Yung, "Mission and Evangelism: Evangelical and Pentecostal Theologies in Asia” in Sebastian C.H.Kim [ed], Christian Theology in Asia. Canbridge, etc: Cambridge University Press, 2008, 250

31 Steckelberger, 130

${ }^{32}$ Rony C. Kristanto, Injil bagi Orang Kaya?: Teologi Kemakmuran sebagai Teologi Rakyat. Yogyakarta: TPK/CBEP Duta Wacana, 2010

${ }^{33}$ Lovemore Togarasei, "The Pentecostal Gospel of Prosperity in African Context of Poverty: An Appraisal"

Exchange, 40 (2011), 336-350.

34 Tong, 77
} 
are quite successful in appreciating aspects of the prosperity gospel which are often overlooked in common commentaries on that doctrine. In term of the struggle against corruption, the spirit of entrepreneurship and optimism promoted by neo-Pentecostalism may produce real entrepreneurs who should be able to find ways to avoid taking part in corruption. Entrepreneurship and optimism also help one not to cease struggling in a frustrating situation where corruption is so rampant and looked irresistible.

Nevertheless, both Kristanto and Togarasei also admit that the prosperity gospel fails to pay an adequate attention to social and political ethics. Togarasei underlines W. Richards' criticism that "the weakness of the Pentecostal gospel is its political irrelevance." In other words, the individual approach of neo-Pentecostalism offers an effective way to overcome psychological barriers. Its contribution, however, is limited if the problem lies in the political structure as in the case of corruption involving the business community.

\section{Evangelicalism and Individual Piety}

Contrary to the neo-Pentecostals, the conservative-evangelicals strongly reject the doctrine of prosperity gospel. Conservative-evangelical teachings are centred on the concept of salvation which is understood as having little to do with material achievement. ${ }^{36}$ The soteriology of the conservative-evangelicals does imply a concept of ethics. They demonstrate a serious concern about individual piety with the family as the broadest context. Conservative-evangelical churches stress on honesty and responsibility in individual and family lives. Such commitment may also be extended to the corporate life within the firms belong to the individuals or families of the church members. However, that moral standard does not equally apply for the context of the larger society. The conservativeevangelicals tend to understand the societal context more a matter of evangelism than ethics. It does not mean that they do not aware of the Christian responsibility on social matters. Indeed they include social responsibility as part of their "methods and strategies." ${ }^{37}$ Yet in addressing the issues of social responsibility they tend to emphasise that the church's involvement must be limited to the spiritual dimension and the individual area. The conservative-evangelicals tend to consider an active political praxis diverts the primary calling of the church which is to proclaim Jesus Christ as the Lord and Saviour.

\footnotetext{
${ }^{36}$ See: Tong, 77-78

37 See: Jan Sihar Aritonang and Karel Steenbrink, A History of Christianity in Indonesia Leiden/Boston: Brill, 2008, 894
} 
In the case of the Chinese-Indonesian business community, conservative-evangelical churches play a role once belonged to the Chinese associations, namely as a forum of business networking and community service. ${ }^{38}$ Since such a role is apolitical in nature whilst corruption has an obvious political dimension, those churches fail to provide a clear, critical message regarding the involvement of their members in corruption.

Hence, as with the neo-Pentecostal, the conservative-evangelicals may serve quite well the businesspeople's psychological needs, such as that related to capacity building, work ethic and motivation. Individuals affiliated with such religious communities may be aware enough of the need to keep honesty and cleanliness in their personal relations. However, corruption often works not only on the personal level but also in the structural one. ${ }^{39}$ Thus, even those who, for a religious reason, try really hard to be honest and clean individuals, are not free enough to avoid involving themselves in corruption which has been so badly infected the structure of their professional network. By 'structure,' I mean both political structure and cultural structure. Corruption in the cultural structure is related to the values and virtues formed in the community. The political inferiority feeling suffered by the ethnic Chinese business community, which leads to the common practice of clientelism, is obviously a psychological problem, but it is also a matter of political and cultural structures.

\section{The Mainstream and Social Justice}

Arguing that conservative-evangelicalism and neo-Pentecostalism have not yet successful enough in helping their community members resist corruption does not mean claiming that the mainstream churches ${ }^{41}$ have been more effective. Despite the sound awareness of social and political ethics in the mainstream's theology, many institutions and projects associated with those churches have suffered from corruption-related problems. Stuckelberger shows examples of the practices of corruption in mainstream churches covering from bribery in elections and appointments of bishops, elders, school principals, and other positions in Christian institutions, to misappropriation of properties and funds

\footnotetext{
${ }^{38}$ Michael Backman, Asian Eclipse: Exposing the Dark Side of Business in Asia. Singapore: John Wiley \& Son, 1999, p. 218

39 See, Stueckelberger, 147

${ }^{41}$ I follow van Kooij and Tsalatsa A in using the term 'mainstream' to refer to the group of Protestant denominations which are active members of the ecumenical bodies including Communion of Churches in Indonesia, World Communion of Reformed Churches or Lutheran World Federation, Christian Conference of Asia, and World Council of Churches; see: van Kooij and Tsalatsa A., 1
} 
belong to the churches. ${ }^{42}$ Also, there is no record indicating that businesspeople who are members of mainstream churches are less affected by corruption. In other words, the mainstream churches have not yet succeeded enough in working out their social ethics at the practical level. One possible problem is that of integrity. The sort of applied theology operated in the congregational level is inconsistent with that reflected in the academics and denomination's elites. The former referred to the old, colonial theology which is closer to that of the conservative evangelical. Also, despite the deep concern of the mainstream camp about social and political moral issues, it tends to give less attention to issues concerning personal and institutional ethics than the conservative-evangelical and neoPentecostal do. Economically speaking, mainstream theologians in Indonesia tend to focus on macro-economic issues, having little interest in corporate ethics and business ethics. Even in their theological reflections on macro-economic issues, corruption is rarely particularly addressed. When I collected the syllabi of postgraduate courses in my Faculty as a preparation for the regular syllabi seminar, I found out that almost all courses in all concentration areas paid enough attention to social-ethical issues. Yet, there was no course which singled out corruption as a crucial theological problem. Also, in a small group meeting of a World Communion of Reformed Churches (WCRC) unit preparing the curriculum of the Global Institute of Theology (GIT) 2012, I failed to convince my colleagues that the GIT should offer a course focusing specifically on the issue of theology and corruption. Those experiences of mine, occurred in the circle of the mainstream Protestant theologians, indicate that the theological works of the mainstream have not yet treated corruption as serious as they did to issues such as poverty, pluralism, gender and local culture.

\section{Can the Available Christian Traditions Produce an Anti-Corruption Theology?}

An attempt to develop a broad spectrum anti-corruption theology drawn from a single Christian tradition is recently presented in the form of doctoral dissertation by Sahat Lumbantobing in the Doctor of Theology Programme of ATESEA Theological Union (ATU) based in Duta Wacana Christian University. Researching the practices of corruption in the Parliament of Indonesia, Lumbantobing, a Methodist minister, suggests a theological response based on the concept of social holiness of John Wesley. Lumbantobing selects

\footnotetext{
${ }^{42}$ Stueckelberger,67-68
} 
Wesley's theology for its integration of the concern for personal piety on the one hand and the commitment to social and political responsibilities on the other hand. Lumbantobing believes that Wesley reemphasises basic doctrinal themes such as grace, justification by faith, holiness, and the new birth to react against the moral collapse in the political area. As such, Wesley provides an integrated theological resource: for personal ethics as well as political ethics. Presenting his theology in practical ways, such as sermon in revival worship and bible study, Wesley's theology is prevented from being too elitist or not explicit enough. Moreover, since the theology of social holiness confronts social and political issues with basic church doctrines, it disallows the reduction of church doctrines into a matter of individual piety. At the same time it prevents the concern for social and political ethics from being alienated from the commitment to individual moral life. ${ }^{43}$

However a direct use of John Wesley's theology for today's Indonesian context would not be responsible enough since Wesley addresses a unique situation in the Britain past. Historian Andrew C. Thompson ${ }^{44}$ argues that the recent enthusiasm particularly among Methodists and Wesleyans to "reclaim" the concept of social holiness has been misinterpreting Wesley's original theology. For Thompson, it is important to notice that the term "social holiness" appears only once in Wesley's writings, namely in the Preface to the edition of Hymns and Sacred Poems, which he published with his brother Charles Wesley in 1739. The term was a reaction against what he interpreted as isolationism being promoted by mysticism tradition. According to Thompson, Wesley's social holiness refers not to social ethics but rather to his theology of salvation which includes the expression of love by and within particular Christian communities. Hence, for Thompson social holiness is a communitarian concept and thus not to be confused with the contemporary concept of social justice.

If Thompson's analysis is accurate enough, Wesley's theology should not be treated as a holistic theological ethics covering all moral concerns of the other theological traditions explored above. Its place is, in fact, somewhere within the conservative-evangelical position. Nevertheless, Wesley's reputation in linking his evangelical model of theology to social

\footnotetext{
${ }^{43}$ Sahat Martua Lumbantobing, Kekudusan Sosial dan Korupsi Politik: Studi tentang Praksis Perjumpaan Kekudusan Sosial John Wesley dengan Perilaku Korupsi Politik di DPR-RI sebagai Model Sumbang Pikir Teologis Kristen. unpublished dissertation, Yogyakarta: UKDW, 2011

${ }^{44}$ Andrew C. Thompson, "From Societies to Society: The Shift from Holiness to Justice in the Wesleyan Tradition" Methodist Review, 3 (2011), 141-172
} 
change demonstrates that it is possible for evangelicalism to play a more sociallyresponsible role than what it normally does. Anyway, a contextual anti-corruption theology should embrace all existing theological traditions rather than looking for one supreme tradition free from the weaknesses of the existing. Concerning the context of the Indonesian business community, what is needed is a model of doing theology which accommodates the interests of the neo-Pentecostals and the conservative evangelicals in building individual piety and personal moral commitment without necessarily underrating the broader social context. At the same time it should affirm the mainstreams' concern for social justice whilst not sharing its negligence on individuality. An attempt to develop such a model of theology therefore should start with wholehearted dialogues between Indonesian different theological camps, particularly the neo-Pentecostals, the conservative-evangelicals and the mainstreams, to synergise theological and ethical resources they have developed so far. Furthermore, to really address the multicultural context of the Indonesian business community, a theology of anti-corruption should also be accountable multi-religiously. Such a theology thus should be included in the agendas of interreligious projects from the dialogue level to the practical partnership one.

\section{Conclusion}

I start this paper with a discussion questioning the effectiveness of religion in resisting corruption. Focusing the Indonesian business community, I argue that corruption is a multidimensional problem containing political as well as cultural factors. The fact that Indonesian businesspeople are no less religious than the rest of Indonesian society makes it interesting to study the actual and potential roles of religions in influencing their attitudes concerning corruption. Among the religions embraced by Indonesian businesspeople, Christianity is worth focusing given its attractiveness among the ethnic Chinese. My concentration is particularly concerning the neo-Pentecostal and the conservativeevangelical traditions given their increasing popularity among the ethnic Chinese businesspeople. However, the mainstream Protestant tradition cannot be overlooked because of its continuing effort to deliver social ethical messages pertinent to the broad context of business. I have been arguing that each Christian theological tradition explored above demonstrates an important moral resource relevant for contesting the context of corruption. Yet standing alone, none of those traditions would be strong enough to 
challenge the multi-dimensional nature of corruption. A sound anti-corruption theology should synthesise the spirit of entrepreneurship and optimism of the neo-Pentecostal, the emphasis on individual piety and its implications for corporate ethics of the conservativeevangelical, and the deep concern for social justice and its political-ethical messages of the mainstream. Finally, to practically address the multicultural context of the Indonesian business community, a Christian anti-corruption theology should be developed in dialogue and partnerships with the other religions. 


\section{References}

Aritonang, Jan Sihar and Steenbrink, Karel, A History of Christianity in Indonesia Leiden/Boston: Brill, 2008

Backman, Michael, Asian Eclipse: Exposing the Dark Side of Business in Asia. Singapore: John Wiley \& Son, 1999

Harian Kompas, 29 November 2011 edition

Korupsi dalam Perspektif Agama-agama [Corruption from the Perspectives of Religions], LP3 Universitas Muhammadiyah Yogyakarta, Government Reform in Indonesia, Koalisi Antarumat Beragama untuk Antikorupsi Yogyakarta, 2004

Kristanto, Rony C., Injil bagi Orang Kaya?: Teologi Kemakmuran sebagai Teologi Rakyat. Yogyakarta: TPK/CBEP Duta Wacana, 2010

Kwik, Kian Gie, Pikiran yang Terkorupsi. Jakarta: Penerbit Buku Kompas, 2006

Lingle, Christopher, The Rise and Decline of the Asian Century: False Starts on the Path to the Global Millenium. Hong Kong: Asia 2000 Ltd, 2000

Lumbantobing, Sahat Martua, Kekudusan Sosial dan Korupsi Politik: Studi tentang Praksis Perjumpaan Kekudusan Sosial John Wesley dengan Perilaku Korupsi Politik di DPR-RI sebagai Model Sumbang Pikir Teologis Kristen. unpublished dissertation, Yogyakarta: UKDW, 2011

Marquette, Heather, Corruption, Religion and Moral Development. Religions and Development Working Paper 42, International Development Department, University of Birmingham, 2010

Prior, John Mansfrod, "The Challenge of Pentecostals in Asia, Part One: Pentecostal Movements in Asia" Exchange, 36 (2007), 6-40

Stueckelberger, Christoph, Corruption Free Churches Are Possible: Experiences, Values and Solutions. Geneva: Globethics.net, 2010

Subhi-Ibrahim, M. and Rukmana, Aan, "Agama untuk Antikorupsi" in Wijayanto and Zachrie, Ridwan [eds], Korupsi Mengorupsi Indonesia: Sebab, Akibat dan Prospek Pemberantasan. Jakarta: Gramedia Pustaka Utama, 2009

The Siauw Giap, "Islam and Chinese Assimilation in Indonesia and Malaysia" in Cheu Hock Tong [ed], Chinese Belief and Practices in Southeast Asia. Petaling Jaya: Pelanduk Publications, 1993

Togarasei, Lovemore, "The Pentecostal Gospel of Prosperity in African Context of Poverty: An Appraisal" Exchange, 40 (2011), 336-350

Thompson, Andrew C., "From Societies to Society: The Shift from Holiness to Justice in the Wesleyan Tradition" Methodist Review, 3 (2011)

Tong, Joy Kooi-Chin, Overseas Chinese Christian Entrepreneurs in Modern China: A Case Study of the Influence of Christian Ethics on Business Life. London, etc: Anthem Press, 2012.

van Koij, Rijnardus and Tsalatsa A., Yam'ah, Bermain dengan Api: Relasi antara Gerejagereja Mainstream dan Kalangan Kharismatik Pentakosta. Jakarta: BPK, 2007

Wijaya, Yahya, "The economic ethics of Christian and Islamic fundamentalism" in Hadsell, Heidi and Stueckelberger, Christoph, Overcoming Fundamentalism: Ethical Responses from Five Continents. Geneva: Globethics.net, 2009

Wijayanto and Zackrie, Ridwan [eds], Korupsi Mengorupsi Indonesia: Sebab, Akibat dan Prospek Pemberantasan. Jakarta: Gramedia Pustaka Utama, 2009

Yung, Hwa "Mission and Evangelism: Evangelical and Pentecostal Theologies in Asia" in Kim, Sebastian C.H. [ed], Christian Theology in Asia. Cambridge, etc: Cambridge University Press, 2008 